\title{
Andries van Aarde as historical Jesus scholar
}

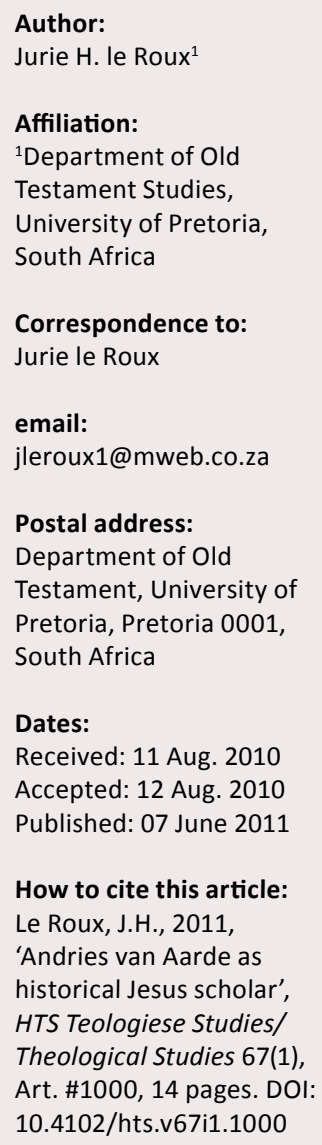

(C) 2011. The Authors. Licensee: OpenJournals Publishing. This work is licensed under the Creative Commons Attribution License.
This article focuses on Andries van Aarde's work on the historical Jesus and especially his book, Fatherless in Galilee, which made an important contribution to historical Jesus study in South Africa. In the first part of the article Van Aarde's historical and social approaches are highlighted, his ongoing reflection on the resurrection described and his work on the Infancy Gospel of Thomas accentuated. In the second part we discuss Van Aarde's depiction of Jesus as someone who grew up fatherless. For Jesus this meant a lifelong struggle against slander and exclusion from the temple and the presence of God. Jesus nevertheless trusted God who filled Jesus' emptiness. Jesus was baptised and then started a ministry, focusing on the outcasts of society. He preached that the kingdom of God had come and that the people of this kingdom could experience God, as well as forgiveness of sins. Jesus died but arose in the kerygma. The article also refers to the struggle of the authors of the New Testament writings to understand and express the Jesus event.

\section{Introduction}

According to Andries van Aarde the Bible is not the primary source of authority for the church but the 'Sache Jesu', the 'cause of Jesus', which is the canon behind the canon. The New Testament can therefore never replace 'Jesus as the revelation' because it only witnesses to the Jesus event; it only mediates the 'cause of Jesus'. Christianity is therefore not primarily built on a book but on a historical person (Van Aarde 2001b:149); this historical person, Jesus of Nazareth, is God's becoming event for humankind. Ordinary Christians meet God in their encountering with Jesus and still experience God through the narratives about Jesus (Van Aarde 2001b:159).

It is, however, important that 'God's becoming event' in Jesus of Nazareth is historically discernable. Historical research has shown that initially there was the Jesus tradition containing the words and deeds of him and then there was the interpretation of this tradition. The tradition and 'the faith assertions by followers, the two-in-one' make up the Jesus kerygma which forms the basis for believers 'to live by the cause of Jesus, which is God's presence for us' (Van Aarde 2001b:150). Thus, for Van Aarde the Jesus tradition and its interpretation form a unity and it can be illuminated by historical study.

In this article we will highlight some aspects of Van Aarde's historical Jesus research by putting Van Aarde in a context, explaining his approach and his multi-faceted depiction of Jesus of Nazareth. We begin, however, with a few remarks on the particularity of Van Aarde's study of the historical Jesus and in the latter part we will focus on his fatherless Jesus.

\section{He followed his own way}

In his great review of research into the historical Jesus, Albert Schweitzer explains why this type of inquiry could attain such heights in Germany. It requires four preconditions in particular: a sound philosophical basis, a critical mindset, historical awareness and religious sense. These four conditions developed into a harmonic unity within the German psyche, which guided the inquiry into the historical Jesus in a very definite manner, to such an extent that 'the greatest achievement of German theology is the critical investigation of the life of Jesus' (Schweitzer 1936:1). A similar undertaking would not have been possible in South Africa. Not only were the four preconditions lacking, be it in part or in their entirety, but the theological climate was not conducive to this type of investigation (cf. Le Roux 1993:107-114). Andries van Aarde's Fatherless in Galilea is therefore probably the first true 'full length' critical history of Jesus that investigates and narrates Jesus' whole life on earth written by an Afrikaans speaking South African.

We can feel the heartbeat of Van Aarde's scholarly work in his historical Jesus research. He has devoted his whole academic life to this theme and his work is appreciated nationally and internationally. He is an extremely hard worker and despite health problems persisted and pursued his scholarly work with great vigour and enthusiasm. Van Aarde nevertheless knows the limits of 
his research and is self-critical: 'From the perspective of critical realism, there are certain weaknesses in each approach' (Van Aarde 2008a:779). With regard to his own work he could have explored the references to alternated states of consciousness (ASC's) more fully, investigated the items of the authentic Jesus tradition more thoroughly and exploited the notion of a 'social type' in his use of the Weberian ideal type more in depth; also he should have been more concrete and less abstract with regard to his profile of Jesus (Van Aarde 2008a:780).

However, in his research of the historical Jesus Van Aarde is always striving for authenticity. 'Authentic' not in the sense of 'what actually happened', but in the Heideggerian way: 'to be true to one's own self, to be one's own person, to do one's own thing' (Van Aarde 2008a:779); this can be applied to Van Aarde in two ways. Firstly, in the way he handled texts; for instance, to study the Infancy Gospel of Thomas (IGT) authentically implied that text analysis as well as its translation had to be 'faithful in terms of this document's "identity"' and in terms of its time and purpose (Van Aarde 2005:830). Secondly, the way in which Van Aarde understands his own craftsmanship; he wanted to be true to his own epistemology, approach and terminology. He rejected, for instance, any accusation of being positivistic just because he used historical criticism, is interested in the overlays of the Jesus tradition or wanted to translate the Jesus tradition to present-day faith communities (Van Aarde 2008a:784-786; Heidegger 1998:96103, 219-222; Grondin 2001c:1-43; Safranski 2000:186-202).

A particular feature of Van Aarde's work as a scholar is to reflect on the ethical and theological consequences of his historical Jesus research for today (Van Aarde 2008a:783). Historical Jesus research 'has a validity and a necessity of its own' because the kerygma about living through faith is based on a historical Jesus, who treated genders as equal, rejected ethnicity and was radically subversive (Van Aarde 2001a:203-204). Seen from this perspective, historical Jesus research is:

fundamental to the credibility of Christianity, in that Christianity is not a 'book-religion' but represents belief patterns witnessed in the New Testament and is modelled on the words and deeds of Jesus of Nazareth, expressed and confessed by Christians as a child of God.

(Van Aarde 2001a:203)

And since Van Aarde 'deliberatelty choose to 'translate' hermeneutically the interpretations of faith by the earliest Jesus followers to present-day faith communities' (Van Aarde 2008:784) the text must therefore be approached in a specific way: the evolutionary historical development of the Jesus tradition must be emphasised. Put differently: exegesis requires a historical sensitivity without which it would be impossible to see and experience this growth of the Jesus tradition as well as its constant interpretation and reinterpretation in and for the communities of faith (cf. Craffert 2008:1-100).

\section{Historical Jesus research is necessary}

In earlier times it was easier - much easier. The proclaimed Jesus was what mattered and knowledge about the historical
Jesus was of no material significance. The final battle was fought at Nicea and Chalcedon and from then on there was no need to go back to what preceded these important creeds (Daßmann 1999:71-124). This might have been the case to this day even, had it not been for a far-reaching event: the rise of a historical understanding or awareness of the world, of humans and of texts during the 19th century. It was the century of history: 'The nineteenth century is in a loaded way the century of history and historiography' (Mehlhausen 1984:643). History and historiography became a means by which people could come to an understanding of themselves: 'Thus, the fundamental basis of modern historical thinking' is the notion 'that history is the way - or the detour - that leads humanity back to self-discovery' (Mehlhausen 1984:643). Through history people wanted to gain insight into themselves and their very being as humans (Barash 2003:1-63). Objects are only really understood after they had been historically understood. Historical understanding has become a way of life, a way of understanding our human world, our everyday life and a way to solve problems (Grondin 2001:115-130). This historical impact was bound to influence in a far-reaching way the inquiry into the historical Jesus (Borg 1991:8-14).

There is, however, also something else: the inaccessibility of the past, the feeling that the past cannot be entered so easily anymore. Despite the discovering of the importance of history for life there was also the feeling of estrangement. This was due to the fatal concurrence of two revolutions, namely the French and the Industrial revolutions; they occurred at the same time and together they revolutionised western thinking and science. Initially all rejoiced in this 'herrlicher Sonnenaufgang' as Hegel called the French Revolution and saw these events as a new dawn in the history of humankind. Ordinary life, however, soon became a terrifying experience and people lived in constant fear because their world has been turned upside down (Ankersmit 2007:141, 1990:133; cf. Kraus 1969:80-113; Le Roux 1998:477-486, 1993:26-27, 2001:444-457). For the first time in western thinking the past was experienced as something strange, remote and inaccessible. An unbridgeable gap between present and past was suddenly experienced. The past became problematic and could not be accessed so easily any longer. At times the 'pastness' of the past became unbearable and the breach between past and present developed into a horrible abyss (cf. Thiselton 1980:103-113). The past became an immeasurable stream of events which flows unendingly towards eternity. No one can control this infinite stream or formulate its meaning in final terms. Each one of us is rather constantly overwhelmed and engulfed by an endless torrent of concrete events without ever mastering it (Weber 1949:147, cf. 1904:146-214, 1920:207-236).

Historical Jesus research in terms of 19th and 20th century biblical scholarship was thus an attempt to overcome these problems and to draw the distant past closer to reach for the unreachable but without avail (cf. Grondin 1999:11, 15, 2001a:1-10, 2001b:152-159, 2001c:1-43; Le Roux 1997:401423). A systematic analysis of the historical Jesus 'even only in 
the sense of a definitive, objectively valid, systematic fixation of the problems which it should treat, would be senseless in itself' (Weber 1949:140). This, however, is not the end of the road because each new attempt to reach the unreachable new and unexpected dimensions of the historical Jesus are discovered (cf. Spivak 1976:lviii-lxvii).

In view of the aforementioned the study of the historical Jesus is extremely complex, difficult and risky and Van Aarde's research is therefore of no small significance to the academic and faith communities in South Africa - particularly as far as his courage, honesty and emphasis on the 'faith value' of historical inquiry are concerned (Van Aarde 2001a:204).

Van Aarde's history bears testimony to his courage. To know the physical Jesus was of little significance to the early church. All that remained of the historical Jesus was a vague memory, a few detached words and the memory of his miracles, his death and resurrection. A biography about the historical Jesus was out of the question. At Chalcedon things took a turn for the worse: '... its doctrine of the two natures dissolved the unity of the Person, and thereby cut off the last possibility of a return to the historical Jesus' (Schweitzer 1936:3). In Christological reflection after Chalcedon the human nature became increasingly subservient to the divine; Jesus became more divine and less of a human being; more the Son of God who descended from heaven than the human who lived in Nazareth. In brief: 'In this divine splendor his human nature paled' (Den Heyer 1996:23-24). Research about the historical Jesus became almost dispensable. The importance of Van Aarde's work thus lies in the fact that it tells South Africans how to get a handle on the past Jesus reality preceding Chalcedon, Nicea, the New Testament and the other non-canonical writings.

Historical honesty is an important trait of Van Aarde's inquiry. Not only is his work an honest quest for the historical Jesus, but it is also an honest endeavour to engage the cutting edge of history; the acid test for every theology lay in its honesty about the past. This is particularly true of the historical Jesus: 'The critical study of Jesus has been for theology a school of honesty' (Schweitzer 1936:5). However, such honesty comes at a price. It might even be traumatic for history destroys what is the acceptable and popular perception of matters. It is rather typical of the nature of history. It is like an iron ball: it destroys, turns things upside down, recreates and rewrites. A historian can sometimes be likened to a smith. With heavy, loud blows he shatters the generally accepted, but unhistorical views of the past (or the historical Jesus) apart (Troeltsch 1913:716, 1922:730; Klapwijk 1970:89-96). Historiography (particularly about the historical Jesus) was (and still is) a treacherous undertaking. In this regard David Friedrich Strauss offers a good example: 'His 'Life of Jesus' was his ruin' (Schweitzer 1936:5). Twenty five years after the publication of his Jesus book, Strauss described the consequences the book had for him: he had to resign from his position at the university, he lost friends and became a lonely man (Schweitzer 1936:97-120). Honesty about Jesus thus comes at a price. And herein lies the importance of Van Aarde's work, namely that he takes us through this historical crucible (that threatens to destroy everything) in order that the importance of Jesus could once again surface. His work does indeed destroy existing views, but it also helps us to take note of other, new perspectives on Jesus.

As stated earlier Van Aarde emphasises that faith and historical information are not mutually exclusive. There are those who maintain that knowledge about the historical Jesus is meaningless. For them historical knowledge is often of minor importance. Faith is indeed not based on historical fact and reconstruction. It is merely incidental, coincidental and cannot vouch for ultimate truths. Knowledge about the historical Jesus is thus incidental and of secondary importance (cf. Du Toit 1985:257-279). In this way, we do not get past Lessing and the eighteenth century's near contempt of history. Between the historical Jesus and the church's Jesus was a nasty and unbridgeable chasm no one could cross. Lessing said he would not even have dared to jump as his legs were too weak (Thiselton 1980:53-63). As a result of the rise of a historical awareness in the 19th century, the view about history changed radically. Now it was being postulated that everything took shape in history and was formed by history (cf. Von Harnack 1908:177-179, 1990:133-138; Gunkel 1926/1927:533; Borg 1987:1-17).

For Van Aarde, too, history is of great significance: '... the Jesus of history is not irrelevant' (Van Aarde 2001a:20). God's salvation took shape in history; God revealed God self in this human, this Jesus. In a human manner God took shape in our human world through the human Jesus. And the trail of this is to be found in the New Testament and in ancient literature. Therefore, faith calls for knowledge about the historical Jesus. Without this, salvation becomes virtual, Jesus becomes a phantom, and all utterances about Christ mere fleeting thoughts (Van Aarde 2001a:18). Or, as Van Aarde summarises it: 'If (historical) inquiry is denied at the doorstep, doubt will come through the window' (Van Aarde 2001a:23).

\section{It has to be historically authentic}

It seems as if Van Aarde's reading of the historical Jesus has two central foci: one is the Jesus tradition and the other its interpretation. And this is the reason for his use of historical criticism: 'Historical criticism, irrespective of plausibilities because of hypothetical theories ... tends to distinguish between "tradition" and "redaction"' (Van Aarde 2008a:783). Whoever works in a historical critical manner has to provide proof of his or her historical skill. This implies that one should continually set one's historical lenses sharper in order that they will show up the past (or the historical Jesus) in a fresh and different manner each time. Precisely how the historical process should take its course is not certain. Everyone gives it his or her own content, or as Albert Schweitzer puts it: 'The historical study of the life of Jesus has had to create its own methods for itself' (Schweitzer 1936:6). In the case of Van Aarde it took shape in a specific manner. In this regard the following is briefly noted.

He listened to the voices of yesterday and of those before yesterday (cf. Schnelle 1999:18-26, 177-214), in other words, 
he has taken the history of research into the historical Jesus seriously. Today, no one can make any meaningful contribution regarding the historical Jesus without taking cognizance of the enormous discussion about this very topic in the 19th and 20th centuries. This discussion forms the historical level of the conceptual horizon from which Jesus should be discussed. He has internalised the discussion of the past two centuries about Jesus and for this reason his work offers in one way or the other a critical reaction thereto (cf. Van Aarde 2008a:789-793). Many influenced his thinking. William Wrede is one of those scholars who has had a remarkable impact on Van Aarde's understanding of the New Testament. Wrede taught him that the canonical gospels were already an interpretation of Jesus. According to Wrede, the Gospel of Mark is a theological work with an apocalyptic interpretation of Jesus. Van Aarde has absorbed this and he also, similar to Wrede, acknowledges that behind the oldest Gospel in the New Testament, Mark, there is an interpreted Jesus. Similarly, Van Aarde knows that a grasp of the historical Jesus is almost impossible (Van Aarde 2001a:32; cf. Schweitzer 1936:328-338). Van Aarde commences his work by referring to the conclusion in Albert Schweitzer's book about Jesus research: everyone will during the course of his or her daily existential struggle learn who Jesus is for him or her (Van Aarde 2001a:1-4; Schweitzer 1936:401); in the last chapter of his book, 'Fatherless ...', Van Aarde specifically focuses on this aspect (Van Aarde 2001a:195-204). Van Aarde's critical engagement with Bultmann is also apparent: aspects such as the New Testament authors' mythological worldview, the distinction made between Geschichte and Historie, the nature of the historical Jesus' work, the historical basis for Jesus' baptism, et cetera, illustrate his critical engagement with Bultmann (Van Aarde 2001a:15, 22-23, 54-57, 60). A very important trait of Van Aarde's historical Jesus research is his involvement with both the Context Group and the Jesus Seminar: he could thus for many years develop along the thoughts and methodology of the leading historical Jesus researchers, which in turn shaped his understanding of the historical Jesus. Lastly, the influence of John Dominic Crossan must be mentioned. Van Aarde's respect for him as a leading contemporary historical Jesus researcher shows in many ways (Van Aarde 2001a:30-32, 62-63, 65-71, 168-169, 188-190, 2008a:784-785). In brief: historical Jesus research has a long history and those who does not take note of it, misses important insights into the life and meaning of Jesus (cf. Le Roux 1997:401-423).

One of the first steps in any historical inquiry involves a critical analysis of sources. That Jesus is God that he is God and human at the same time - as the creeds of the fourth century proclaim - are later interpretations that cannot be used as primary sources of the times of Jesus (cf. Pelican 1971:173-210). It is the earliest sources that must be probed. The problem, however, is that such sources are scarce and actual historical information is sparse (Van Aarde 2001a:58). This does not, however, imply that one should take risks (Van Aarde 2001a:55, 2011:forthcoming). Every source that could possibly shed light on the historical Jesus, Van Aarde consulted with circumspection (Van Aarde 2005:827-829). In every piece he wanted to find echoes of a Jesus past and for this reason he wanted to listen attentively. Even myths and mythological language were important to him: '... myths represent an interpreted reflection on the identity of Jesus, just as any other attestation to his words and deeds does' (Van Aarde 2001a:27, cf. 28-30, 48-50). After Van Aarde had thoroughly tested his sources and had arranged them in a hierarchy from the earliest to the latest source, he could go back to the earliest evidence. Of course, this was no easy task. In order to follow Van Aarde, one has to keep his dating of sources in mind at all times.

Van Aarde contends that initially, knowledge about Jesus was transmitted orally and that it was only 25 years later that any one, (Paul, who had not known Jesus personally), began to write it down. At about the same time, that is, in the fifties of the 1st century, a sayings gospel that scholars refer to as Q, appeared. Later, two redactions of this gospel's core (the 'formative stratum') followed. Just like the canonical gospels, the final redactional stratum reflects the struggle of Palestinian village communities in north Galilee and south Syria at a time the Israelites had to come to terms with the loss of their main cultural symbol, the temple in Jerusalem (Van Aarde 2004:711-738). According to Van Aarde (1999:804), there are commonalities between some of Jesus' sayings that Mark reported and the two layers (a formative and redactional one) of the Sayings gospel Q. Luke and Matthew took many Jesus sayings from the later redaction of $Q$, which they then revised (Van Aarde 2001a:109).

The gospel of Mark appeared around 70 CE (Van Aarde 2004:724-726). Apart from the Sayings gospel Q, Mark became a source for the gospel of Luke in $85 \mathrm{CE}$ and between 85-90 CE it became a source for Matthew. Towards the end of the 1st century John's gospel was developed independently from Mark, Luke and Matthew. During the course of the 2nd century certain Gnostic works, which are relevant for Jesus studies, appeared (Van Aarde 2001a:10; cf. Le Roux 1996:653-670). Certain Jesus sayings in the Gospel of Thomas exist independently of the canonical gospels and were and possibly pre-date Mark.

\section{Social models are indispensable}

According to Van Aarde there need not be tension between historical criticism and social anthropological models and therefore he argues 'for an epistemological continuity between a historical-critically sensitive Jesus research and an anthropologically sensitive Jesus research' (Van Aarde 2008a:768, 778). Historical criticism 'as a practical method and anthropological theory are both necessary in historical Jesus research because the data require it' (Van Aarde 2008a:787).

In our times Biblical Studies has become multidisciplinary and interdisciplinary (Van Aarde 2001a:31). Van Aarde therefore declares: 'The historical investigation practiced in this book (Fatherless ...) is multidisciplinary in nature' (Van Aarde 2001a:14). It is particularly evident in the socialscientific and narratological reading of texts. A social-scientific understanding of the New Testament is of the utmost importance to Van Aarde. Although initially guided by Bruce 
Malina and Paul Hollenbach, Van Aarde has developed his own social-critical thinking. These perspectives assisted him to reach a better understanding of the historical Jesus: 'Several aspects of my portrayal of the historical Jesus have become to me more and more intelligible as my application of social-scientific criticism has increased over the years' (Van Aarde 2001a:42). At one juncture this influence was decisive: the starting point of his historical Jesus. Van Aarde does not begin his narration with Jesus at the age of thirty and with his baptism, but starts at his birth (Van Aarde 2001a:72-81). More precisely, the incomplete family to which Jesus was born and in which he grew up. This is the result of Van Aarde's social criticism. In his view all communities comprise particular social institutions, such as family, the economy, politics and religion. In the Mediterranean world of the 1st century family was central. What happened there, determined one's life. Life outside family structures and without family ties was hell (Van Aarde 2001a:45). And that is why Van Aarde decided to start with Jesus' birth and family context (Van Aarde 2001a:75).

Van Aarde's social understanding of texts also helped him to describe the Jerusalem group and depicts its 'contribution' to our understanding of the historical Jesus. According to Van Aarde Jesus never intended the establishment of the church but after his execution he lived forth through the stories of those who experienced his resurrection; these narratives gave rise to different Jesus movements, one of which was the Jerusalem group. James the brother of Jesus was the leader of the group because he witnessed the resurrection. He did not follow Jesus during his lifetime but after his resurrection experience he became a follower of Jesus and one of the group's 'pillars of faith' in Jerusalem. This group experienced their Israelite heritage intensely. They were steeped into Israel's life style and conventions. These earliest followers of Jesus immersed themselves in the Hebrew Scriptures. They interpreted Jesus as God's messiah to Israel and they believed that Jesus restored Israel as an ethnic group. This group followed religious practices of the 'old' Israel and was reluctant to preach the gospel outside Jerusalem, They were the 'creators' of the idea of 'the Twelve' which represented the apocalyptic 'true Israel'. Accordingly, they idealised their existence by describing themselves as the 'eschatological Israel' and consequently disliked Samaritans (Van Aarde 2004:721-735).

The Jerusalem group used apocalypticism to understand themselves, to express their faith as the church of Christ, to explain the resurrection and to make intelligible the believers' expectation of the coming judgement (Van Aarde 2004:714-715). This group utilised the formula 'buried, resurrected and ascended' to depict Jesus as the apocalyptic martyr sitting on God's right hand. Due to their apocalyptic mindset they, institutionilised baptism as 'spiritual baptism' and Jesus' last meal as a means of participation in God's 'spiritual kingdom'. This 'spiritual baptism' in the name of the Father, the Son and the Spirit incorporated someone into the 'heavenly kingdom' and made the novice a disciple. And those who participated in the meal were members of the in- group, the fellow believers belonging to the Jerusalem group. Apocalypticism 'can therefore be seen as the mother of the Jerusalem's group theology ... and unthinkable without the belief in the resurrection from the death' (Van Aarde 2004:717).

When a group, like the Jerusalem group, is identified and described historically it sheds light on people, texts and opposing trends. Paul for instance resisted himself against the Jerusalem group because they were so narrow-minded and mainly focused on their own national Israelite identity. Paul saw himself as the 'apostle for the Gentiles'. He emphasised the unity with Jesus as a faith experience and explained the concept 'faith' by terms like 'to be in Christ' or 'to be in the Spirit'. Paul believed that the 'old' had passed and he proclaimed the emergence of a 'new' spiritual entity including Israelites and non-Israelites (Van Aarde 721724). Dissident voices like that of Paul also highlight the particularity, the individuality of the Jerusalem group.

\section{Ideal types are invaluable}

An ideal-type is on the one hand one-sided and on the other hand a synthesis. It overemphasises one or more aspects of reality and is therefore a one-sided depiction of the world. According to Weber, it furthermore synthesises 'a great many diffuse, discrete, more or less present and occasionally absent concrete individual phenomena'. All these phenomena are selected and organised according to one-sided viewpoints and then blended 'into a unified analytical construct' which is called an ideal-type (Weber 1949:90). When such an ideal-type is applied to history it does not render historical truth because 'we are (merely) applying a purely analytical construct created by ourselves' (Weber 1949:96). An idealtype is therefore a mental construct and called 'ideal' because it is nowhere in reality to be found. It is rather a utopia reflecting the idealistic 'reality', which we ourselves have created (Weber 1949:91).

For Van Aarde an ideal type is a tool to overcome the obscurity of history because 'das Buch der Geschichte [ist] für jede Gegenwart ein im Dunkel abbrechendes Fragment' (Gadamer 1990:203). An ideal type establishes in an intelligible manner interrelationships between fragmentary historical and social events; endeavours to make sense of the historical Jesus and his social world. Or as he has put it himself: 'In my historical Jesus research I used the model of an ideal type to develop a construct of Jesus as a fatherless figure who called God his father' (Van Aarde 2008a:269). This does not imply a historical literary or an anthropological correspondence between his ideal type and 1st century Galilee. It is merely a conceptual tool to understand (however limited) something of the historical Jesus and his world; a tool enabling him to follow the traces in the New Testament leading to a possible clearer understanding of Jesus of Nazareth; a tool to get as close to 1st century social reality as possible (Van Aarde 2008a:275277). To accomplish this, the ideal type must be made or constructed by means of canonical and non-canonical texts. The task of the scholar can therefore be compared to that of an 
archaeologist and the constant search for the 'most authentic' evidence. By means of textual criticism the New Testament scholar must penetrate the layers of the text in order to detect the most authentic witness about the historical Jesus.

An important impetus for the formulation of an ideal type was Jesus' craving for the remission of sin and his affinity for fatherless people. Jesus voluntary submitted himself to John's baptism for the remission of sins, then severed his links with the Baptist and became involved in the lives of the fatherless and husbandless. To understand this Van Aarde made an ideal type of an individual in 1st century Herodian Palestine who had been healed 'from the stigma of being a fatherless son' and one 'who started a ministry of healing/ forgiving "sinners"' amongst those who also experienced the harshness of sin, the sin of a child without a father. Or as Van Aarde himself said:

My aim was to provide an explanation of the historical figure Jesus who, trusting in God as his father, destroyed conventional patriarchal values while caring for the fatherless within the macro-sociological framework of family distortion in Herodian Palestine.

(Van Aarde 2008a:269)

In all likelihood Van Aarde's ideal-type of Jesus may not accurately resemble the historical Jesus, but it highlights in striking manner what might have been the experiences of a fatherless boy in the Mediterranean world during the 1st century (cf. Craffert 1999b:1-21).

\section{It is an ongoing process}

Van Aarde's study of the historical Jesus does not follow a fixed, unchangeable programme. Historical criticism is never applied rigidly, social criticism can take different forms and ideal types are not always the same. This can especially be seen in Van Aarde's study of the resurrection belief. There is a growth in Van Aarde's thinking about this theme. In his earlier works it was formulated too concise and compact because he lacked a model to express his thoughts on this theme adequately. In the motif of a 'new creation' and the theory of a trajectory he then later found the means to articulate his views more clearly. It is, however, his particular use of a trajectory that gives his work on the historical Jesus a certain sharpness because the resurrection is not limited to one meaning or context anymore but gets a life of its own in the long history from the Old to the New Testament, from Israel to the early church. Put differently, by using the model of a trajectory he broadened the debate and made the resurrection part of a history of ideas which took shape over many years and which can be divided into five historical stages.

To explain a trajectory Van Aarde refers to the early church's theology. There is a development in this theology. It is not merely a conglomerate of separate events and individuals who believed, preached and wrote but they were in many ways interrelated. Jesus did not think like Paul and the other way round. Paul and Mark had their agreements but there were also grave differences. Origen represents a further development in the trajectory of the early church as well as Athanasius and Augustine. These differences not only emphasise a theological plurality but also constitute a line of thought consisting of individual creative moments in the one theology of the early church. Each individual moment must be understood in its particularity and its place within this one history must be understood. This implies that its relation to preceding or subsequent phases must be determined and related to each other. In short, a trajectory consists of a sequence of texts, convictions and theologies embedded in specific eras in history and whose individuality must be understood historically (Van Aarde 2011:forthcoming).

The first link is dated in an early period in Israel's theology when death was mainly understood in terms of Sheol and the snares of death terrified people. An example of this thinking can be found in Psalm 18:4-6:

With Death's breakers closing in on me, Belial's torrents ready to swallow me, Sheol's snares every side of me, Death's traps lying ahead of me, I called to Yahweh in my anguish, I cried for help to my God; from his Temple he heard my voice, my cry came to his ears.

(New Jerusalem Bible)

In this first link Sheol is prominent: the body went to Sheol. It was a step in the direction from something to nothing; a crossing from the world of human beings to the dismal Sheol; a place where God cannot be praised; an unbridgeable abyss between the dead and the living, the living and God (Van Aarde 2011:forthcoming).

A second link in this trajectory can be found in Isaiah 26:19:

Your dead will come back to life, your corpses will rise again. Wake up and sing, you dwellers in the dust, for your dew will be a radiant dew, but the earth will give birth to the shades.

(New Jerusalem Bible)

Emphasis is laid on 'dust' and 'dew' which both refer Israel. 'Dew' signifies revitalisation, restoration, resuscitation and regeneration and refers to the dead, to 'the dwellers in the dust', to Israel the corporate personality, which will rise again. Within this second link an important shift took place: Israel was individualised and there is a 'life after death' (Van Aarde 2011:forthcoming).

With the third link we have moved into the era of Alexander the Great, the process of Hellenisation and the decisive influence of Plato. We can also distinguish between the region east of the Mediterranean and the one west. In the west Plato's views of the separation of body and soul and the latter's immortality became dominant in the reflection on death and resurrection. Paul belonged to this specific phase of the trajectory and was also shaped by Plato's thinking and stressed Jesus' final victory over death. He explained the resurrection in terms of a 'creatio ex nihilo' and emphasised an ethics of obedience to Jesus Christ and the practising of God's righteousness. Put differently: those who participated in the faith of Jesus' resurrection had to reflect the righteousness of God in this world (Van Aarde 2011:forthcoming).

The fourth link connected resurrection to encouragement. 
In 1 Thessalonians 4:13-18 Paul consoled the believers with the resurrection of Christ and its comforting implications for the believer and then said: 'Therefore encourage one another with these words' (1 Th 4:18). Believers shared in the power of the conqueror of death and should therefore not fear or mourn without hope (Van Aarde 2011:forthcoming).

References to the fifth link can be found in late New Testament texts such as Matthew 27:45-56 narrating how people were empowered by the event of the crucifixion in Jerusalem: the graves were opened, the dead were raised, they entered Jerusalem and many people witnessed this event. By means of apocalyptic imagery the believers' participation in Christ's resurrection is underscored and the hope of their own resurrection in future strengthened. This view, however, refers back to earlier Jewish texts during the Maccabean period, which assured the martyrs of their own, personal resurrection. According to the Enoch tradition for instance Sheol will give back what he has taken. Part of this 'individualisation' of the resurrection is a tomb cult. At the grave of Joseph a cultic movement like the Samaritans developed and something similar was established around the grave of Jesus in Jerusalem. And the Emmaus narrative in Luke 24 illustrates Jerusalem's importance and the essence of participation in the resurrection: the followers of Christ move from Jerusalem to Emmaus and from Emmaus to Jerusalem and experienced that their hearts were burning within them (Van Aarde 2011:forthcoming).

Van Aarde thus showed the notion of resurrection to be multi-dimensional and integrated in a history of theology. There was a deepening of thinking from the early fears of Sheol to the apocalyptic expectation of personal resurrection and this history must be taken seriously. There are five historical links of phases but perhaps one can add a sixth: the believer's own time and context. Van Aarde therefore refused to limit the meaning of the resurrection to the people of the 1 st century and therefore viewed theological reflection on the resurrection's significance for him (and the faith community) as part of his scholarly work (Van Aarde 2008a:782-786). According to him the resurrection must be understood in terms of a new creation and those participating in this faith must become 'new creations' filled with hope, contributing to a new South Africa and searching for justice and moral virtue without which no society can exist in dignity (Van Aarde 2011:forthcoming).

\section{An example of craftsmanship}

Van Aarde's lifelong study of the IGT is a fine specimen of his craftsmanship as well as his devotion to the historical Jesus research. Everything we have already said culminates in this lifelong commitment to the IGT. Van Aarde is interested in the Jesus tradition as well as its re-interpretations by different Jesus movements in the early church. His painstaking attention to detail in the study of the IGT not only illustrates his interest in the 're-interpretation' of the tradition but also the nature of his craftsmanship.
First of all he devotes himself for long periods to the study and research of a specific text and theme. Or as he himself said: his research of the IGT:

started 27 years ago, when as a young lecturer in the then Department of Greek I taught apocryphal gospels and used the Gospel of Peter and the Infancy Gospel of Thomas as sample studies. This year, 2005, I have been a lecturer in a permanent capacity for 25 years, and I am grateful to put my research on this ancient and provocative text on paper at last.

(Van Aarde 2005:827-828)

This 'paper' was another doctoral dissertation submitted at the Department of Ancient Languages at the University of Pretoria in 2005.

His investigation of the IGT also reveals Van Aarde's meticulous analysis of a text. In his search for an authentic text of the IGT he first of all made a painstaking analysis of the Codex Atheniensis, which was a laborious undertaking because he had to study the text from microfiche in the Africana section in the library of the University of Pretoria. There he thoroughly investigated the text grammatically and translated all nineteen chapters. A 'process that demanded considerable energy and perseverance' (Van Aarde 2005:828).

Due to his rigorous scholarly work he came to realise that the Codex Atheniensis (Cod Ath Gr 355) was not the most authentic text of the IGT. He then started to travel in search of the most reliable text:

My research travels took me from Israel (Tantur Institute for Theological Studies) to the Catholic University of Leuven in Belgium, to the USA (Westar Institute in Santa Rosa, California and the McCormick Theological Seminary in Chicago, Illinois) and finally to Egypt (Evangelical Theological Seminary in Cairo, Sint Catherine in Sinai and Nag Hammadi in Upper Egypt).

(Van Aarde 2005:829)

Through hard work Van Aarde finally determined the more authentic text. The first version of the IGT in Greek was published by Fabricius in 1703 and in 1874 Constantin von Tischendorf was responsible for the publication of two manuscripts in Greek and one in Latin (Vat Lat 4578). One Greek text (the Evangelium Thomae Graece A) was longer than the other (the Evangelium Thomae Graece B). These Greek texts form part of the Codex Sinaiticus which was once kept in the St Catherine's monastry but are now in London. The shorter redaction is called the Codex Sinaiticus ( $\mathrm{Gr}$ 453) and the longer one the Codex Sinaiticus ( Gr 532) and according to Van Aarde the shorter version is the more authentic one. The Codex Sinaiticus ( Gr 532) is gnostic and this can be seen in the antipathy against the family of Jesus and the Israelites (Van Aarde 2005:828-829).

It was to this shorter rendition to which Van Aarde devoted much research and even translated it into Afrikaans 'which in itself was no small task!'; he formulated his contribution as follows:

I think that one of my most important contributions to the research on the IGT is the argument that this second-century document has neither an Orthodox nor a Gnostic orientation, but that its context is rather the early Ebionite Christianity.

(Van Aarde 2005:830) 
According to Van Aarde Codex Sinaiticus (Gr 453) is the more authentic text and is compiled from many stories about the young or adult Jesus. Apparently the 'Jesus as the Teacher'section forms the nucleus of this 2nd century infancy Gospel and underscores the central theme that the child Jesus and not the adults (rabbis and elders) was the real teacher. It especially becomes clear in his confrontation with the rabbis. Jesus excelled as teacher and some viewed him as 'either a god or an angel'. He was so filled with divine knowledge and wisdom that some people thought him to be of divine origin. It is, however, interesting to note that Jesus, the divine child acted in a very humane way to his family and friends. Jesus' positive reaction towards his biological family also implied a positive attitude towards other Israelites. The Israelites were the extended family of Jesus. And the recognition of Jesus' powers by the rabbis is also an acknowledgement of where salvation is to be found. Therefore the Jesus of the IGT 'is a god-child portrayed as a human' (Van Aarde 2006:360).

Van Aarde not only analysed the text of the IGT thoroughly but also investigated its Ebionite context. He criticised the existing research on the IGT and suggested that it be 'supplemented by the insights of cultural anthropology, and particularly by those of ethnic theory' (Van Aarde 2006:365). What was needed was a theory of ethnicity to explain the typical features of an 'Israelite identity' as situated in an Ebionite context, embodied in Ebionite thought and expressed in the IGT. In this regard he found the notion of 'habitus' extremely helpful because it incorporated two approaches to ethnicity: primordialism and constructionism. According to primordialism, ethnic groups have very strong emotional ties to a family, territory, language, customs and religion. These intense feelings of attachment are strengthened by memories of the past, shared ancestors and a shared history (Van Aarde 2006:366). Primordialism helped Van Aarde to identify in the opening verse of the IGT the very strong bonds, which linked the child Jesus to his brothers and other Israelites. Jesus is honoured by his brothers as lord and master whilst remaining humble and kind to them. This can only be understood from a primordial perspective: this Ebionite society was closely knit together by a strong ethnic identity and feelings of togetherness, closeness and fellowship (Van Aarde 2006:365368). Constructionism, on the other hand, deals more with the rational element in ethnicity. Applied to the Ebionite community, the emotion of belonging was one aspect of their identity but the constructive thinking and planning how to stay within the group by means of responding 'to God's divine election and to maintain the covenantal status (or the ethnic identity of Israel)' was another important part of this community's uniqueness (Van Aarde 2006:375).

Up to now we have devoted much attention to some theoretical aspects of Van Aarde's historical Jesus research. His focus on the Jesus tradition as well as its re-interpretation, his emphasis on historical as well as social critical approaches, his use of ideal types, his ongoing reflection on the resurrection and his enormous contribution to the study of the IGT. In the following the focus is narrowed down to Van Aarde's views on life and times of Jesus the fatherless.

\section{Jesus' World}

Van Aarde has his own story of Jesus of Nazareth, which at times may shock but is mostly moving, touching and challenging. Whoever 'beholds' this Jesus, is struck by his immense humanity. Jesus was a 'nobody'; that is how he was born, how he lived and died: 'Jesus of Nazareth died as he was born: a nobody among nobodies' (Van Aarde 2001a:43). However, these 'nobodies' (the marginalised ones, the children, the women), had so intensely experienced his love and compassion that he lived on in their memory. This story begins at his birth, in the country of his birth.

Jesus was born in Galilee (cf. Van Aarde 2001a:72, 83-85). The Galilean world, into which he was born, was multilingual and was occupied by gentiles and Israelites. Mixed marriages were commonplace and because of their mixed descent, Galilean Jews were often referred to as 'Samaritans'. Towns and cities could be found all along the Sea of Galilee and also a few miles further on. There were often temples, dedicated to the emperor and all kinds of gods, a royal palace, military fortifications and residences with marble tiled floors where the aristocrats led a high life in the cities and towns; then there were peasants who were living close to the sea. Some of them earned their living as fishermen going out to sea in old decrepit boats, whilst others farmed on small plots of agricultural land and when forced by poverty and debt, they resorted to other trades. One such possibility was to become a woodworker (Van Aarde 2001a:75; cf. Botha 2000:1-18).

Then there was the priestdom's power play. A rigid religious policy was formulated in Jerusalem that influenced the entire community in a radical manner. No one could escape the power of this temple-state. Everything centered around purity and impurity and the society was regulated and controlled by laws and endless regulations. It was an exclusivist society that was hierarchically organised and in which each one's position was clearly determined. Then there were those officials who gathered the temple taxes. They furthermore had to ensure that the laws were implemented and that the community led 'pure' lives. (Van Aarde 2001a:74-75). The pressure was often just too much for the ordinary peasants. The double taxes imposed by the temple in Jerusalem and the Herodian Dynasty forced them off their land and led to the disintegration of families (Van Aarde 2001a:128).

Family was central to every Jewish community in Galilee. It was a man's world and all power vested with the man. Men lived in the place of their birth and its immediate vicinity for their entire life. There they were connected to a network of family ties. People looked up to a man and he was a role model for the younger ones (Van Aarde 2001a:120). The father was the central figure in the family. On the one hand he represented God in the family and on the other he had to ensure that God is worshipped in family context. God and family were connected in a particular way. In order to experience God, one had to be part of a family:

One had to belong to a family to enjoy God's blessings, and, within the family, the father's status was divinely ordained. And so, the 
divine and the human met each other at the most intimate level, the familial.

(Van Aarde 2001a:121)

Family, strong family ties, the relationship with other families and the strong role of the father determined a child's identity and course in life. It was a social map according to which he could orientate and legitimise himself and by which he could find his way in this world (Van Aarde 2001a:119). Whoever had to live outside the family circle, had a life of hell.

\section{A category five child was born for us}

Strict precautions were in place to ensure that people marry within the family group. Thus the expansion of the 'sacred progeny' or 'Abraham's children' (Abraham's physical descendants) could be ensured (Van Aarde 2001a:131). Jesus would, however, remain on the outside. Who exactly his mother was, is not known. Van Aarde (2001:101-102, 147-148, 151) does not pertinently say that she was unmarried when she was expecting the child Jesus. It was also possible that her husband may have abandoned her during her pregnancy (as was often the case). Such a woman was then called a 'whore' and her child was regarded as the sinful result of an adulterous relationship (Van Aarde 2001a:73). Apparently, Jesus was such a child (Van Aarde 2001a:80). He would have had to live with what constituted a shame in the eyes of the community. As far as the officialdom of the temple-state in Jerusalem was concerned, he was nothing else but a category five child (Van Aarde 2001a:132).

Jewish religious leaders categorised people into different groups ranging from the holy and less holy ones to the impure. The priests were ranked in the top position, followed by the Levites, full-blooded Jews and priests' children. There were basically seven categories of people and this categorisation was used to determine who was allowed to marry who. Category five is of interest to us. This group consisted of the half-castes, the fatherless (those whose fathers were unknown), foundlings and the castrated. The fatherless included inter alia those born from forbidden relationships. Hermaphrodites and people with deformed genitalia belonged to category six. They were in any event not allowed to marry. People of any other ethnic descent belonged to the seventh category. They fell outside the Covenant and the people of Israel were not allowed to mix with them. (Van Aarde 2001a:132). According to Van Aarde we should look for Jesus in category five: 'The image of the historical Jesus as the fatherless carpenter ... fits the ideal-type of the fifth category' (Van Aarde 2001a:133).

Jesus could hardly have been born into worse circumstances. He was a 'nobody' and an outcast from the very beginning (Van Aarde 2001a:60-61,110-111). Some hints of his illegitimacy can be found in literature and we shall cite a few. Jesus says in the Thomas gospel (105) that he who does not know his father or his mother is the child of a whore and is therefore sinful. Mark 6:3 refers to Jesus as the son of Mary. There is no reference to his father. According to John 19:9, Pilate asked Jesus where he had come from. Jesus did not answer, which was in line with a rabbinic directive: if a person does not know who his father or mother is, then he should keep quiet (Van Aarde 2001a:74). The females in Jesus' genealogical register were of questionable character: Tamar misled Judah and from their union were born Perez and Zerah (Gn 38:6-30); Rahab was a prostitute (Jos 2:1); Ruth was a foreigner and an outsider (Rt 4:1-17) and Solomon's mother 'had been Uriah's wife' (Mt 1:6) whose death David had contrived for the sake of his own desires. Jesus' ancestry consisted of disreputable people and he had no honor to defend: 'Matthew's version of Jesus' genealogy places him among the disreputable ... These foremothers of Jesus were dishonorable people ... there was no honor te defend' (Van Aarde 2001a:150).

Being fatherless meant a bleak future for Jesus:

- His status would have been known to all and he would have been treated like a cripple.

- He would not have been able to rid himself of the sin (society had imposed on him).

- There would never have been a father with whom he could identify or who would have accepted him as a child within a family (Van Aarde 2001a:133, cf. 2001a:5, 14-15, 46, 77, $78,118)$.

- He would have lived without identity and would never have been one with the Judean community.

- He would not have been part of the true Israel, nor of Abraham's ancestry.

- He would only have been allowed to enter the temple's court for gentiles and no further.

- He would not have been able to fall in love with a purebred Israelite woman.

- He would only have been able to marry an impure girl.

- He would have had to live like someone outside the covenant, like someone who didn't know God and whom God didn't notice either (Van Aarde 2001a:74, 119, 126127).

- In short, Jesus indeed was a 'nobody'.

\section{The adult Jesus}

Initially, Jesus could have been a peasant. In all likelihood he was not an easy-going person and aspects of his revolutionary behaviour later on in life might have already manifested in his earlier life. Initially, he was part of the Galilean peasant community and lived away from his family. Heavy taxation might have forced him back to his earlier trade as carpenter (Van Aarde 2001a:77). We are probably familiar with some aspects regarding Jesus' formative years (Van Aarde 2008:779780):

- He was unmarried (Van Aarde 2001a:77). His descent and strict marital conventions probably prevented him from marrying: 'Radically opposed to what the conventions of the temple cult of Jerusalem prescribed, he (was), an unmarried outsider' (Van Aarde 2001a:183).

- His relationship with his family was strained. He did not have a good relationship with his mother and even less so with his brothers (Van Aarde 2001a:77).

- He was acutely conscious of sin. The fact that he was an illegitimate child made him a sinner; by this, 'systemic sin' 
is meant. He carried the scorn society had imposed on him as an illegitimate child (Van Aarde 2001a:4-5, 132-134, 182-183).

- He fantasised about a father. As a fatherless and familyless person, he fantasised about having a father, rather than being a father himself. As a fatherless son who relied on his mother for everything, he did not really identify with her. (Van Aarde 2001a:65). From her he had received what he could receive from her and therefore he still yearned for a father (Van Aarde 2001a:121).

- He trusted God as a child would. As a fatherless child, he turned to God and experienced God as a father whom he could always approach. Briefly: In Jesus' struggle with the consequences of his being fatherless, God became his father (Van Aarde 2001a:134, 153-154).

- He yearned for a family and for family ties; a family he would belong to and within which he would feel at home. From the very reason that he was not part of the normal family and experienced the bitterness of being a fatherless child and so the desire for family arose. Van Aarde 2001a:149).

\section{Jesus and John the Baptist}

At some stage a popular movement (led by a certain John, known as 'the Baptiser') came into being. Although discontent with Roman rule may have played a role in its establishment, the humiliating temple ideology provided the real spark. According to this ideology Jerusalem determined whose sins would be forgiven and how it would happen. According to their categorisation of people the priests could even decide who was entitled to have access to God and who not (Van Aarde 2001a:68). This was the reason for John's protest. An apocalyptic expectation was a trait of John's baptism: he expected that God's judgement was imminent and for this reason people should confess their sins and be cleansed (Van Aarde 2001a:113).

On a given day Jesus came to John to be baptised. That John had baptised people is, according to Van Aarde, historically true (Van Aarde 2001a:66, cf. 55-63). Jesus's baptism was, however, later interpreted from a specific theological perspective and was recounted or rewritten in a specific manner. (Van Aarde 2001a:60). Why did Jesus want to be baptised? Like John, he too was probably convinced about sin, repentance, forgiveness and conversion (Van Aarde 2001a:66). But what was the nature of Jesus' awareness of sin? Jesus suffered under the yoke of 'sinful sickness'. He wanted to rid himself of the oppressive stigma of a fatherless child. Society made him a sinner, hence the need for forgiveness of sin (Van Aarde 2001a:53). After his baptism Jesus returned to Galilee. There, he did not pursue John's practice of baptism, but started his own ministry (Van Aarde 2001a:182-183). This ministry was characterised by the following:

- Jesus mixed with sinners. Those who, according to the temple theology of the day, were not part of Abraham's lineage, he made part of God's family (Van Aarde 2001a:69).
- He healed people spiritually. Those who were aware of their sin could taste forgiveness. (Van Aarde 2001a:67-70; cf. Craffert 1999a:88-129).

- He healed people who experienced all kinds of strained family relationships. In the 1st century Mediterranean world the family was extremely important and each member's life was narrowly interwoven with the fate of the others. If these family bonds were broken it resulted in personal distress and calamity. Family conflict, however, was a constant reality. Possession by devils could have been caused by intense family strife and therefore Jesus encouraged those sufferers to leave their homes and 'become part of a surrogate (fictive) family with God as Father' (Van Aarde 2000:227). The break with the synagogue also caused severe family tension which led to the disintegration of the individual and traces of this can still be found in the Sayings Gospel Q and the Gospel of Thomas: 'Blessed are you who hunger, for you will be satisfied' (Q 6:12; cf. GosThom 69:2) and 'Blessed are you when(ever) they hate you (and) persecute you' (GosThom 68; cf. Q 6:22). Jesus healed the individual by incorporating him or her in the alternative family of Jesus followers (Van Aarde 2000:229).

- He taught about God's direct and unmediated presence. According to the temple priests, the outcasts had to live as if there was no God. According to Jesus, they could experience God's presence notwithstanding their status (as outcasts) and without intercessors, such as temple officials (Van Aarde 2001a:68, 77, 113, 114).

- He had a particular experience of God. Van Aarde refers to it as an 'alternate state of consciousness' (Van Aarde 2001a:12, 76) and 'his foundational experience of God' (Van Aarde 2001a:196, 197). What exactly it was is uncertain, but perhaps it reinforced Jesus' religious conviction that God was his father, that he was his child and that the kingdom of God was inclusive.

- He referred to the kingdom of God. John was of the opinion that it was still in the future and that it would come in apocalyptic fashion. According to Jesus, it had already arrived. To this kingdom belong the spiritual descendants of Abraham and members of this kingdom are called 'the family of God' (Van Aarde 2001a:53, 54, 66, $67,68,149)$.

\section{The nature of Jesus' ministry}

Jesus' ministry was revolutionary. It was directed at the outcasts, the outsiders and the impure. It is most apparent in his care for children. He really felt for the outcasts within the Jewish community: fatherless children who grew up in the streets and slums. Jesus, the fatherless child, saw the need and cruel fate of others who, too, were fatherless (Van Aarde 2001a:135-154). His work takes on particular significance when understood in the light of the ancient custom of child rejection. Although Jews and Christians did not practice it, it was a well-known practice at the time to abandon newborn babies to die. This was often the fate of unwanted children: those who were disabled, born from illegitimate relationships, the deformed and deranged, those who were without an eye 
or an arm, the blind, lepers, the deaf and the dumb. In order to justify this terrible deed it was often alleged that the children were demons or were filled by some or other evil spirit (Van Aarde 2001a:139-140).

Jesus thus focused on the weakest element in society. $\mathrm{He}$ wanted to change their fate by making them part of a family, namely God's family. According to Van Aarde, the Evangelium Infantium in Mark 10:13-16 provides an excellent illustration:

People were bringing little children to Jesus to have him touch them, but the disciples rebuked them. When Jesus saw this, he was indignant. He said to them: 'Let the little children come to me, and do not hinder them, for the kingdom of God belongs to such as these. I tell you the truth, anyone who will not receive the kingdom of God like a little child will never enter it.' And he took the children in his arms, put his hands on them and blessed them.

(Mk 10:13-16, New International Version [Author's emphasis])

This passage (in particular, the emphasised sections) must be understood in close relation to Jesus' healing miracles. Terms and expressions are used that are peculiar to descriptions of his healings:

- people were brought to Jesus (a typical expression in the synoptic gospels' descriptions of the healings)

- he had to touch them (in the synoptic gospels it is only used in relation to the miracle stories and in reports about people raised from death)

- the disciples rebuked them (this expression is used in the New Testament in relation to the miracle stories)

- they wanted to hinder the children (latter having a connection with a 'miraculous exorcism' in Mt 19:14 and Mk 9:38-41)

- the fact that Jesus took the children in his arms or embraced them, indicates a certain affection (Diodurus Siculus used this expression during the 1st century BCE in a context of child healings)

- Jesus put his hands on the children and blessed them (which is indicative of a typical rite in the practice of healing) (Van Aarde 2001a:135-140).

What constitutes the revolutionary element, the difference in Jesus' ministry? It lies in the fact that he confronted the community's ideology and values head-on. He opposed the patriarchal family system and chose in favour of the outcasts ... the impure, the imperfect, those alienated from God, 'the people living in darkness' (Mt 4:16). Moreover, he used a child and not a man or the head of a family, as model to gain access to the kingdom of God. One has to become like a child to inherit the kingdom of God, not like a man or a father figure. In the aforementioned passage in Mark children are being healed of the social scorn that sticks to them because of a society's ideology; they are admitted to the kingdom of God; they serve as models: 'I tell you the truth, anyone who will not receive the kingdom of God like a little child, will never enter it' (Mk 10:15). Because Jesus had chosen in favour of the outcasts, he gave new meaning and significance to the miserable lives of the oppressed:

among whom were women and children living at the fringe of society because they were the nobodies (the divorced and the fatherless, the widows and the orphans) to whom patriarchy gave no place amidst the honourable.

(Van Aarde 2001a:148)

\section{He died and rose again}

Jesus challenged the temple ideology of his time and confronted society head-on. He angered his fellow villagers and roused the ire of the Pharisees, the Herodians, priests and elders in Jerusalem. His confrontation with the authorities probably cost him his life: 'The kind of life Jesus lived led to his death' (Van Aarde 2001a:189). One day, things went too far and after he had a fit of rage in the temple, the Romans captured Jesus and crucified him. (cf. Van Aarde 2001a:168-169). He died in unknown circumstances and his remains were not buried in a family grave (Van Aarde 2001a:78; Craffert 1999c:85-101); Jesus died as a nobody and was probably buried with other nobodies. His followers, however, regarded his death as 'a filial act of obedient submissiveness to God, his heavenly Father' (Van Aarde 2001a:134).

That would have been the end of everything, had it not been for the fact that Jesus' followers began to talk about him. In their stories he rose from the dead: 'Jesus arose in the kerygma' (Van Aarde 2001a:185). In other words, 'Jesus lived on through the retelling of his cause.' As a result, Jesus movements were founded that served as a vehicle for people to speak about their 'resurrection experiences'. To them it was as if they had experienced the risen Jesus 'in an alternate state of consciousness' (Van Aarde 2001a:185). Eventually, the church was founded. This was not something Jesus had ever contemplated happening (Van Aarde 2001a:184). His followers began to interpret his work and his death in such a way that the church furthered his basic thoughts: the church was a gathering of nobodies who called God 'Father' and who considered one another as equals (Van Aarde 2001a:188, cf. 202-204).

\section{He was captured in words}

Jesus' followers also began to write about him. How would they go about it? Much time had lapsed between the actual events and the recording thereof. Van Aarde's book gives the reader a glimpse of the early church's struggle to grasp the incomprehensible and to express that which cannot be expressed. (Van Aarde 2001a:155-183). All the eventual writings about the historical Jesus (like the New Testament) have one enormous limitation: they have lost the historical Jesus. This lost could be explained as follows:

- When people began to write about Jesus for the first time, the Jesus events were already part of the past. Direct access to Jesus' past was not possible anymore. By the time people began to contemplate this history and write about it, it was already too late: the bygone Jesus reality had already disappeared. Hence, to this day, the Jesus event defeats any understanding by historical reason and can therefore never be fully grasped, thoroughly observed or fully described from what the New Testament records. Whenever Jesus' past (or any historical event for that 
matter) is studied, it leaves historians or New Testament scholars disconcerted because their grasp falls desperately short (Goosen 1998:55).

- All that remained of the Jesus past are the 'the tracks, the marks, the signs left by the event in her flight before thought' (Goosen 1998:56; author's translation from Afrikaans). In other words, all the historians or New Testament scholars can go by are the tracks of the Jesus event in the New Testament. Not the bygone reality in its fullness, but the marks and signs of the historical Jesus. What we thus know about the Jesus past does not pertain to the actual event and will always elude us (cf. Derrida 1997:102-107).

- A sense of loss and mourning must be peculiar to the historian or New Testament scholar. When the Jesus past was verbalised, the particular (the historical Jesus) was immediately lost; when the Jesus past was put into language, it was generalised and that which was particular to the event (the Jesus event) was immediately lost (Derrida 1995:377); this constitutes an enormous loss. A loss that can never be reversed. Hence, the overwhelming sense of mourning. Because the loss is absolute, the mourning is absolute. Nothing can be done about it. The historian or New Testament scholar can but 'cry for the irreplaceable loss and his own impotence in the wake of it, cry for the ashes that the singular had left behind as witness of her fleeting presence' (Goosen 1998:70). Or as Derrida has stated: 'Deep down, deep down inside, the eye would be destined not to see but to weep' (Caputo 1997:326; Le Roux 1998:477-486).

- Every effort to describe Jesus was thus historically determined in its entirety. Paul, John and others took what was available and based upon that described Jesus. Therefore, nothing in the New Testament is extra-mundane and out of the ordinary; not a single form of expression (language, image, and concept) was foreign at the time. The description of Jesus in the New Testament was fully contemporary: it reflects the (limiting) thought pattern of the Mediterranean world during the 1st century. As a result, we have conflicting ways of portraying Jesus (cf. the following section).

\section{Was he a miracle worker?}

When the authors of the New Testament began to put the Jesus experience into words, they had to integrate a number of things: He was a human being, yet there was something celestial about him; he was fatherless, yet he had God as his father; he was a rejected child without identity, yet he eventually became the child of God. How were the authors to present this dichotomy about Jesus?

There was the endeavour of the synoptic authors. These authors followed Greek thinking; in terms of Greek thinking it was simple to bring a divine and a human nature together. Someone of divine origin could appear in the form of a human being and could even share in the fate of humans. A child born from a god as well as a human reconciles the divine and the human in him. Such a child was then called 'son of god' and was capable of performing great heroic acts. Such a reconciliation of the divine and the human posed no problem to the Greeks. The divine nature of such a son of god did not destroy his true human nature and vice versa. To them it was a mystery and a paradox which simply had to be accepted in life. All attention was then fixed on the life of such a godman: the miracles and heroic deeds he performed. In some instances these sons of god were regarded as saviours and were even worshipped in cult. Some of them died but rose again from death. Through certain rites worshippers could share in the god-son's death and resurrection (Van Aarde 2001a:155-157).

It is almost as if in the synoptic gospels Jesus is seen and understood through the lens of Greek thought. Using this Greek tradition the authors of the synoptic gospels could describe Jesus' birth as a miracle. Virginal birth was an ordinary occurrence. Christians in the pagan world were aware of stories about such births in Egypt, Greece, Anatolia and in other regions. Sketches and drawings depicting such supernatural births have been found in houses in Herculaneum and Pompeii. Such portrayals 'provide a clear indication that miraculous birth stories were common and well-known' (Van Aarde 2001a:104). In some Greek myths the mother of a god-son was indeed a virgin. Perseus was the son of the virgin, Danaë, and the god, Zeus. Zeus impregnated Danaë by means of a golden ray that shone through a small window (Van Aarde 2001a:162). Van Aarde's book makes a significant contribution to our understanding of the commonness of such births: 'Contemporary sketches and portrayals of divine birth and/or virginal conception and adoption ... were well-known when the New Testament was written' (Van Aarde 2001a:165).

Someone who had a miracle birth could perform miracles. In the Greek world supernatural powers were the result of such a miracle birth. Asclepius was one such example. Apollo pulled him from his mother's womb and he became a diviner and supernatural healer (Van Aarde 2001a:160). Jesus was another example. He confirmed his divine authority through his miracles. It was acceptable for Christians coming from the Jewish world to talk about Jesus in such terms. Figures such as Moses, David and the prophets were also holy men who had experienced the spirit of Jahwe and who were capable of performing great deeds. Jesus was a similar figure: he has a transcendental spirit and performed miracles. In brief, 'In the first type of the combination of the divine and human, the divine figure was a miracle worker filled with the Divine Spirit' (Van Aarde 2001a:158). Furthermore, the fact that Jesus, the Son of God, according to Matthew (1:18-25) and Luke (1:26-38) had a virginal conception was thus nothing out of the ordinary for people in the 1st century. Such miraculous divine conceptions fitted in with Jesus, the miracle worker and healer (Van Aarde 2001a:165).

\section{Jesus was different}

Paul and John thought differently about it. Jesus was a preexistent being who became human. Philippians 2:6-11 (which 
is probably a pre-Pauline hymn) is a brilliant expression of Paul's thinking: 'Who, being in very nature God ... made himself nothing, taking the very nature of a servant, being made in human likeness'. In this context there was no room for virginal births and miracles. Paul's Jesus does not perform any miracles either. This self humiliation of the pre-existent Christ had consequences even for the believer's everyday life: 'Your attitude should be the same as that of Christ Jesus' (Phlp 2:5).

Van Aarde emphasises the difference between these two types of thought: 'In a certain sense, these two types were mutually exclusive' (Van Aarde 2001a:158). In die synoptic gospels' miracle stories Jesus is presented in a triumphant way: the Son of God who had a supernatural birth and who performed miracles. For Paul Jesus' deeds were characterised, not by power, but by weakness and vulnerability, even on the cross. John, on the other hand, emphasises the paradox that a pre-existent being, who in his very nature was God, could become fully human (Van Aarde 2001a:161).

These two examples illustrate the point that it is impossible to reach the authentic Jesus behind the texts. Apparently, the New Testament authors themselves did not know how to capture him in language. And when the historical Jesus was captured in words, the authors lost him. When they recorded the Jesus past, they lost the Jesus event.

\section{Who then was his father?}

We still need to answer this question. But before we do so, two issues need to be clearly understood. One is that Jesus was fatherless. Van Aarde emphasises it more than once: 'no biological father played a role in his life' (Van Aarde 2001a:108); 'no one knew ... that Joseph was his father' (Van Aarde 2001a:109); 'there is no trace of a father in Jesus' life in historical Jesus material' (Van Aarde 2001a:118). And the other issue is: Jesus called God 'father'. Jesus' yearning for a father was fulfilled by God himself: 'For Jesus, God filled this emptiness' (Van Aarde 2001a:118). Frankly, a biological father does not really fit into Van Aarde's Jesus story. Such a person was not really necessary. Yet, Jesus is called 'the son of Joseph'.

According to Van Aarde the Joseph-Jesus link is a legend that developed only after Jesus' death. It was probably meant to obviate rumours about Jesus' illegitimacy. In the synagogues and the Academy in Jamnia his fatherless state amounted to immorality. The Joseph legend was consequently designed to save the Jesus message (Van Aarde 2001a:113). Why Joseph? In a way, it was obvious. In the Old Testament Joseph represents the region of Jesus' origins: it was the region where the northern tribes had established themselves and where the Joseph tribe played a prominent role (Van Aarde 2001a:82108). According to Luke the world could have been described in terms of concentric circles: first Judea, then Samaria and lastly Rome, representing the larger world. Joseph was closely linked to Samaria. Eventually he became for the Pharisees the antipode to Judah; a people of half-breds, a people between Jahwe's people and the gentiles: a group of exiles (Van Aarde 2001a:98). Because of the Joseph link Jesus of Galilee became linked to the Samaritans and the outcasts. In Luke's parable of the Good Samaritan (Lk 10:30-35) Jesus fulfils the role of both the Samaritan and the Israelite (Van Aarde 2001a:111).

This Jesus-Joseph link also links Jesus to the Joseph of Genesis 37-50. This connection assisted the early church in explaining another aspect of the historical Jesus' life. Joseph, too, was the victim of gossip mongering. He was rejected by his brothers and sold for twenty pieces of silver, but was finally elevated to deputy king over Egypt. There are many similarities with Jesus, the son of Joseph. He, too, was despised and humiliated. He was reviled as a sinner, a Samaritan and an illegitimate child. Yet he triumphed. Joseph became the epitome of forgiveness and compassion (Gn 50:17), whilst Jesus loved the cosmos despite all the hatred against him (Van Aarde 2001a:94-95).

\section{A final word}

Van Aarde's work about the historical Jesus represents a highlight in Biblical Science in South Africa. It forces us to think historically, to probe the earliest sources about Jesus, to appreciate Jesus as a 1st century Mediterranean person and to see his human nature in totality. Van Aarde allows us to understand the struggle involved in recording the Jesus event. Every attempt was historically determined and even excluded other attempts. A firm grasp on the historical Jesus was and still is almost impossible. Yet, Van Aarde's work does suggest that we know enough to draw an outline of the historical Jesus. What we certainly know about is the historical Jesus' radical compassion for others. Ultimately, Van Aarde's sketch of Jesus is different, even shockingly so, but that is precisely what constitutes its beauty and its appeal.

Van Aarde is a church man; hence the hope that his historical Jesus would also have meaning for the faith community. He is aware of the possibility that secularisation and postmodernism may undermine the Jesus kerygma (the church's faith interpretations through the ages) as well as that the church as institution may disappear and that the Christian Bible may lose its canonical authority. It is against this background that one should again look for the significance of the historical Jesus and that believers should have the courage of their conviction to seek the historical Jesus, that is, stripped of all later interpretation (Van Aarde 2001a:204).

Such a quest for the historical Jesus has great meaning for the seeker. Everyone will discover who this Jesus is for themselves in their daily life. This is also in a special way true for Van Aarde. His book is dedicated to his father with whom Van Aarde did not have a good relationship. Van Aarde knew the pain of a fatherless child and for this reason the fatherless Jesus appealed to him. He learnt who Jesus was and what he can still mean to people (Van Aarde 2001a:6; cf. Schweitzer 1936:401).

Schweitzer was right: Who occupies himself with the historical Jesus is saying more about him or herself than it says about the historical Jesus. Herein lies the appeal and challenge of Van Aarde's book about the historical Jesus (Schweitzer 1936:4-6; cf. Bultmann 1951:7). 


\section{References}

Ankersmit, F., 1990, De navel van de geschiedenis, Historische Uitgeverij, Groningen. Ankersmit, F., 1993, De historische ervaring, Historische Uitgeverij, Groningen. Ankersmit, F., 2007, De sublieme historische ervaring, Historische Uitgeverij, Groningen.

Barash, J.A., 2003, Martin Heidegger and the problem of historical meaning, Fordham University Press, New York.

Borg, J., 1987, Jesus: A new vision, Harper Collins, San Francisco, CA.

Botha, P.J.J., 2000, Everyday life in the world of Jesus, Biblia Publishers, Pretoria.

Bultmann, R., 1951, Jesus, J.C.B. Mohr (Paul Siebeck), Tübingen.

Caputo, J.D., 1997, The prayers and tears of Jacques Derrida, Indiana University Press, Indianapolis, IN.

Craffert, P.F., 1999a, Illness and healing in the Biblical world: Perspectives on healthcare, Biblia Publishers, Pretoria.

Craffert, P.F., 1999b, Mediating divine powers: Perspectives on religion in the biblical world, Biblia Publishers, Pretoria.

Craffert, P.F., 1999c, Meeting the living among the dead: Burials, tombs and the afterlife, Biblia Publishers, Pretoria.

Craffert, P.F., 2008, The Life of a Galilean Shaman: Jesus of Nazareth in anthropologicalhistorical perspective, Matrix: The Bible in Mediterranean Context, vol. 3 , Cascade Books, Eugene, OR.

Daßmann, E., 1999, Kirchengeschichte II/2, Kohlhammer, Stuttgart.

Den Heyer, C.J., 1996, Opnieuw: Wie is Jezus?, Meinema, Zoetermeer.

Derrida, J., 1995, Points ... University Press, Stanford, CA.

Derrida, J., 1997, Limited Inc., Northwestern University Press, Evanston, IL.

Du Toit, A.B. (ed.), 1985, Handleiding by die Nuwe Testament, NG Kerkboekhandel, Pretoria.

Du Toit, A.B., 1985, 'Die historiese Jesus en die verkondigde Christus van die Evangelies', in A.B. du Toit (red.), Handleiding by die Nuwe Testament, pp. 257-279, NG Kerkboekhandel, Pretoria.

Gadamer, H.G., 1990, Wahrheit und Methode, J.C.B. Mohr, Tübingen.

Goosen, D., 1998, 'Verlies, rou en affirmasie: Dekonstruksie en die gebeure', Fragmente 1, 54-79.

Grondin, J., 1999, Hans-Georg Gadamer, J.C.B. Mohr, Tübingen.

Grondin, J., 2001a, Der Sinn für Hermeneutik, Wissenschaftliche Buchgesellschaft, Darmstadt.

Grondin, J., 2001b, Einführung in die Philosophische Hermeneutik, Wissenschaftliche uchgesellschaft, Darmstadt.

Grondin, J., 2001c, Von Heidegger zu Gadamer, Wissenschaftliche Buchgesellschaft, Darmstadt.

Gunkel, H., 1926/1927, 'The "historical movement" in the study of religion', Expository Times 38, 532-536. doi:10.1177/001452462703801202

Heidegger, M., 1998, Zijn en tijd, SUN, Nijmegen.

Klapwijk, J., 1970, Tussen historisme en relativisme, Van Gorcum \& Comp, Assen.

Kraus, H.-J., 1969, Geschichte der historisch-kritischen Erforschung des Alten Testaments, Neukirchener Verlag, Neukirchen.

Le Roux, J.H., 1993, The story of two ways: Thirty years of Old Testament scholarship in South Africa, Verba Vitae, Pretoria.

Le Roux, J.H., 1996, 'Andries van Aarde se Matteusinterpretasie', HTS Teologiese Studies/Theological Studies 52(4), 653-670.
Le Roux, J.H., 1997, 'Our historical heritage', Old Testament Essays 10(3), 401-423.

Le Roux, J.H., 1998, 'Israel's history and a sense of loss', Old Testament Essays 11(3), 477-486.

Le Roux, J.H., 2001, 'No theory, no science', Old Testament Essays 14(3), 444-457.

Pelican, J., 1971, The emergence of the Catholic tradition (100-600), University of Chicago Press, Chicago, II.

Safranski, R., 2000, Heidegger en zijn tijd, Olympus, Amsterdam.

Schnelle, U., 1999, Einleitung in das Neue Testament, Vandenhoeck \& Ruprecht, Göttingen.

Schweitzer, A., 1936, The quest of the historical Jesus, A \& C Black, London.

Spivak, G.C., 1976, 'Translator's preface', in J. Derrida (ed.), Of grammatology, pp. ixIxxxvii, The John Hopkins University Press, Baltimore, MD.

Thiselton, A.C., 1980, The two horizons, Pater Noster, Exeter.

Troeltsch, E., 1913, 'Historiography', in J. Hastings (ed.), Religion and ethics, pp. 716-723, T \& T Clarke, Edinburgh

Troeltsch, E., 1922, 'Ueber historisch und dogmatische Methode in der Theologie, Gesammelte Schriften II, 729-753.

Van Aarde, A.G., 1999, 'The historicity of the circle of the Twelve: All roads lead to Jerusalem', HTS Teologiese Studies/Theological Studies 55(4), 795-826.

Van Aarde, A.G., 2000, 'Understanding Jesus' healings', Scriptura 74, 223-236.

Van Aarde, A.G., 2001, Fatherless in Galilee: Jesus as child of God, Trinity Press International, Harrisburg, PA.

Van Aarde, A.G, 2001, "The "cause of Jesus" (Sache Jesu) as the canon behind the canon', HTS Teologiese Studies/Theological Studies 57(1\&2), 148-171.

Van Aarde, A.G., 2004, 'Jesus and the Son of Man', Ephemerides Theologicae Lovanienses 80(4), 423-438. doi:10.2143/ETL.80.4.542105

Van Aarde, A.G., 2004, 'The earliest Jesus group in Jerusalem', Verbum et Ecclesia 25(2), 711-738.

Van Aarde, A.G., 2005, 'The infancy Gospel of Thomas: Allegory or myth - Gnostic or Ebionite', Verbum et Ecclesia 26(3), 826-850.

Van Aarde, A.G., 2006, 'Ebionite tendencies in the Jesus tradition: The Infancy Gospel of Thomas interpreted from the perspective of ethnic identity', Neotestamentica 40(2), 353-382.

Van Aarde, A.G., 2008, “"Anthropological rabbits" and "positivistic ducks": An experiential reflection on Pieter Craffert's "shamanic Jesus", HTS Teologiese Studies/Theological Studies 64(2), 767-798.

Van Aarde, A.G., 2008, 'Public-theological debate - who was the real Jesus?', Acto Patristica et Byzantica 19, 264-289.

Van Aarde, A.G., 2011, 'Tekste, ko-tekste en kon-tekste van die leë graf in die Jesus tradisie', In die Skriflig (forthcoming).

Von Harnack, A., 1908, Das Wesen des Christentums, Heinrichsche Buchhandlung, Leipzig.

Von Harnack, A., 1990, Marcion: The Gospel of the alien God, Labyrinth Press, Durham.

Weber, M., 1904, 'Die "Objektivität" sozialwissenschaftlicher und sozialpolitischer Erkenntnis', in Schriften zur Wissenschaftslehre, pp. 146-214, J C B Mohr (Paul Siebeck), Tübingen (Digitale Bibliothek Band 58: Max Weber. Berlin: Direct Publishing).

Weber, M., 1920, 'Die protestantischen Sekten und der Geist des Kapitalismus', in Gesammelte Aufsätze zur Religionssoziologie I, pp. 207-236, J C B Mohr (Paul Siebeck), Tübingen (Digitale Bibliothek Band 58: Max Weber. Berlin: Direct Publishing).

Weber, M., 1949, The methodology of the social sciences, The Free Press, New York. 